\title{
Interfacial Behavior and Activity of Laccase and Bilirubin Oxidase on Bare Gold Surfaces
}

\author{
Dmitry Pankratov, ${ }^{\dagger, \dagger}$ Javier Sotres, $^{\dagger}$ Alejandro Barrantes, ${ }^{\dagger}$ Thomas Arnebrant, $^{\dagger}$ and Sergey Shleev ${ }^{*},{ }^{\dagger}, \S$ \\ ${ }^{\dagger}$ Biomedical Sciences, Health \& Society, Malmö University, 20506 Malmö, Sweden \\ ${ }^{\ddagger}$ Kurchatov NBIC Centre, National Research Centre "Kurchatov Institute", 123182 Moscow, Russia \\ ${ }^{\S}$ A. N. Bach Institute of Biochemistry, 119071 Moscow, Russia
}

\section{Supporting Information}

ABSTRACT: Two blue multicopper oxidases (MCOs) (viz. Trametes hirsuta laccase (ThLc) and Myrothecium verrucaria bilirubin oxidase $(\mathrm{M} v \mathrm{BOx}))$ were immobilized on bare polycrystalline gold ( $\mathrm{Au})$ surfaces by direct adsorption from both dilute and concentrated enzyme solutions. The adsorption was studied in situ by means of null ellipsometry. Moreover, both enzyme-modified and bare Au electrodes were investigated in detail by atomic force microscopy (AFM) as well as electrochemically. When adsorbed from dilute solutions $(0.125$ and $0.25 \mathrm{mg} \mathrm{mL}^{-1}$ in the cases of $T h \mathrm{Lc}$ and $M v \mathrm{BOx}$, respectively), the amounts of enzyme per unit area were determined to be ca. 1.7 and $4.8 \mathrm{pmol} \mathrm{cm}$, whereas the protein film thicknesses were determined to be 29 and $30 \AA$ for $T h \mathrm{Lc}$ and $M v \mathrm{BOx}$, respectively. A well-

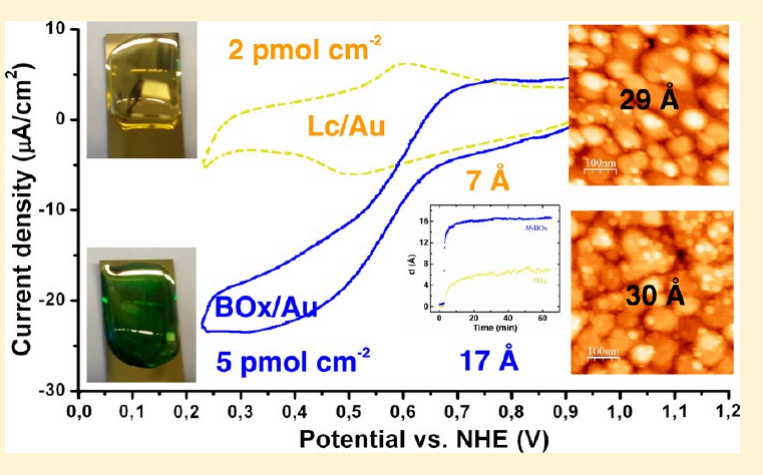
pronounced bioelectrocatalytic reduction of molecular oxygen $\left(\mathrm{O}_{2}\right)$ was observed on $\mathrm{M} v \mathrm{BOx} / \mathrm{Au}$ biocathodes, whereas this was not the case for ThLc-modified Au electrodes (i.e., adsorbed ThLc was catalytically inactive). The initially observed apparent $k_{\mathrm{cat}}^{\mathrm{app}}$ values for adsorbed $\mathrm{Mv \textrm {BOx }}$ and the enzyme in solution were found to be very close to each other (viz. 54 and $58 \mathrm{~s}^{-1}$, respectively $\left(\mathrm{pH} \mathrm{7.4,25}{ }^{\circ} \mathrm{C}\right)$ ). However, after $3 \mathrm{~h}$ of operation of $M v \mathrm{BOx} / \mathrm{Au}$ biocathodes, $k_{\mathrm{cat}}^{\mathrm{app}}$ dropped to $23 \mathrm{~s}^{-1}$. On the basis of the experimental results, conformational changes of the enzymes (in all likelihood, their flattening on the $\mathrm{Au}$ surface) were suggested to explain the deactivation of MCOs on the bare $\mathrm{Au}$ electrodes.

\section{INTRODUCTION}

"Blue" multicopper oxidases (MCOs) (e.g., ascorbate oxidase $(\mathrm{AOx})$, bilirubin oxidase $(\mathrm{BOx})$, ceruloplasmin $(\mathrm{Cp})$, and laccase $(\mathrm{Lc})$ ) are copper-containing enzymes efficiently catalyzing oxygen $\left(\mathrm{O}_{2}\right)$ reduction directly to water $\left(\mathrm{H}_{2} \mathrm{O}\right)$ without the formation of highly reactive oxygen species. ${ }^{1,2} \mathrm{Lc}$ was the first redox enzyme for which direct electron transfer (DET)-based bioelectrocatalysis was demonstrated as early as in 1978. ${ }^{3,4}$ Nowadays, the mechanism of the MCO-catalyzed bioelectrocatalytic reduction of $\mathrm{O}_{2}$ is quite well understood. (See graphical and textual details about the mechanism in Supporting Information (SI), Supporting Figure S2. ${ }^{1,5-7}$ ) In spite of this, a scientific dispute concerning the electrochemical behavior of high-redox-potential MCOs (i.e., redox enzymes with redox potentials of the $\mathrm{Cu}-\mathrm{T} 1\left(E_{\mathrm{T} 1}\right)$ varying from 0.6 up to $0.8 \mathrm{~V}$ vs $\mathrm{NHE}^{7}$ ) adsorbed on gold (Au) electrodes has been taking place since the end of the 1990s.

The debate was initiated by several pioneering studies concerning $\mathrm{Lc} / \mathrm{Au}$ electrochemistry in which well-pronounced low-redox-potential Faraday processes (with midpoint potentials of about $0.4 \mathrm{~V}$ vs NHE) related to the adsorbed enzyme were observed without the efficient bioelectrocatalytic reduction of $\mathrm{O}_{2}$ on enzyme-modified Au electrodes. ${ }^{8,9}$ Later, a similar situation was observed for many different MCOs (e.g., Lc, BOx, and $\mathrm{Cp}$ ) adsorbed on bare and modified Au surfaces. ${ }^{6,7,10-12}$ However, the reason for the absence of bioelectrocatalytic activity was not clearly identified, and in order to explain the experimental results, several suggestions were made. These included both simple, long-standing explanations in the field of redox protein/metal interface electrochemistry, ${ }^{13}$ associated with enzyme denaturation on bare $\mathrm{Au}$ surfaces or/and the absence of a heterogeneous ET between $\mathrm{Au}$ and active centers of MCOs, ${ }^{14,15}$ as well as a sophisticated hypothesis involving the formation of inactive forms of MCOs as a result of an unnatural ET pathway resulting from enzyme orientation specifically by the trinuclear $\mathrm{Cu}$ cluster ( $\mathrm{Cu}-\mathrm{T} 23)$, which was assumed to be in DET contact with the Au surfaces. ${ }^{6,7,11,12,16}$

Recently, the well-pronounced DET-based bioelectrocatalytic reduction of $\mathrm{O}_{2}$ on $\mathrm{Au}$ electrodes modified with $\mathrm{Lc}$ and $\mathrm{BOx}$ was demonstrated. It should be emphasized, however, that bioelectrocatalysis was observed only in the case of atomically planar $\mathrm{Au}(111)$ electrodes, ${ }^{17,18}$ specifically modified polycrystalline Au surfaces, ${ }^{19,20}$ and 3D (porous) Au electrodes. ${ }^{21-25}$ It was suggested that clear yet short-lived bioelectrocatalytic

Received: June 28, 2013

Revised: January 20, 2014

Published: February 24, 2014 
responses on $\mathrm{Au}(111)$, which is a highly ordered and smooth surface, were registered because the protein was either held more tightly or there were fewer "side routes" for ET as a result of decreased surface roughness ${ }^{17}$ (i.e., better wiring of BOx on $\mathrm{Au}(111)$ was obtained compared to that on the polycrystalline surfaces). Bioelectrocatalysis on modified polycrystalline $\mathrm{Au}$ was attributed to proper enzyme orientation ${ }^{20}$ along with enzyme stabilization. ${ }^{19}$ Similar reasoning could also be given to explain the observed $\mathrm{O}_{2}$ bioelectroreduction process, when porous $\mathrm{Au}$ electrodes were used, because the immobilization of $\mathrm{MCO}$ in 3D Au electrodes could favor the exposure of the active site of the immobilized enzymes ${ }^{22}$ and/or stabilize enzyme molecules incorporated into nanocavities, ${ }^{21}$ as theoretically predicted in $2001 .^{26}$

Two questions, however, are still not answered: (i) could MCOs directly adsorbed on bare polycrystalline planar $\mathrm{Au}$ electrodes, which are not nanostructured or chemically modified, efficiently catalyze $\mathrm{O}_{2}$ electroreduction? If yes, then (ii) why was $\mathrm{O}_{2}$ bioelectroreduction not registered in many previous attempts concerning $\mathrm{MCO} / \mathrm{Au}$ electrochemistry?

To answer these questions, electrochemical, ellipsometric, and AFM studies of planar polycrystalline Au surfaces modified with Trametes hirsuta $\mathrm{Lc}$ (ThLc) and Myrothecium verrucaria $\mathrm{BOx}(\mathrm{M} v \mathrm{BOx})$ were performed as described below.

\section{EXPERIMENTAL SECTION}

Materials. $\mathrm{Na}_{2} \mathrm{HPO}_{4}, \mathrm{NaOH}, \mathrm{KH}_{2} \mathrm{PO}_{4}, \mathrm{~K}_{3}\left[\mathrm{Fe}(\mathrm{CN})_{6}\right], \mathrm{NaF}$, and $\mathrm{H}_{2} \mathrm{SO}_{4}$ were obtained from Merck (Darmstadt, Germany). Citric acid, 2,2'-azino-bis(3-ethylbenzothiazoline-6-sulfonic acid) (ABTS), and bovine serum albumin were from Sigma-Aldrich (St. Louis, MO, USA). All chemicals were of analytical grade. Buffers were prepared with water $\left(18 \mathrm{M} \Omega \mathrm{cm}\right.$ at $\left.25{ }^{\circ} \mathrm{C}\right)$ purified with a PURELAB UHQ II system from ELGA Labwater (High Wycombe, U.K.). Different $\mathrm{O}_{2}$ concentrations were established by bubbling air and oxygen from AGA Gas AB (Sundbyberg, Sweden) through the solution.

Enzymes. Basidiomycete Trametes hirsuta, strain T. hirsuta 56, was obtained from the laboratory collection of the State Research Institute of Protein Biosynthesis (Moscow). Extracellular Trametes hirsuta laccase $(T h \mathrm{Lc})$ was isolated from the culture media and purified to homogeneity following well-known procedures. $^{6}$ The enzyme homogeneity was confirmed by SDS-PAGE (Supporting Figure S2). $\mathrm{BOx}$ from Myrothecium verrucaria fungus $(\mathrm{M} v \mathrm{BOx})$ was obtained from Amano Enzyme Inc. (Nagoya, Japan) and was additionally purified by Dr. Olga V. Morozova (A. N. Bach Institute of Biochemistry, Moscow, Russia) using gel-filtration and ion-exchange HPLC. Both preparations of the enzymes were stored in $10 \mathrm{mM}$ phosphate buffer at $\mathrm{pH} 6.5$ and $-18{ }^{\circ} \mathrm{C}$ because the storage stability of both enzymes is close to maximal at this $\mathrm{pH}$ value. The preparations were thawed and airsaturated for $2 \mathrm{~h}$ before use in order to avoid the possible presence of resting forms, viz., partially reduced enzymes. ${ }^{27}$ The concentration of Lc and BOx was measured spectrophotometrically at 228.5 and 234.5 $\mathrm{nm}$ using BSA as a standard. ${ }^{28}$

Enzyme Assay and Kinetic Studies. The specific activity of $M v \mathrm{BOx}$ and $T h \mathrm{Lc}$ in homogeneous solution was determined by estimating the initial rates of $\mathrm{O}_{2}$ consumption using an Oxygraph Clark $\mathrm{O}_{2}$ electrode from Hansatech Ltd. (Norfolk, England) at $25^{\circ} \mathrm{C}$ with constant stirring. An appropriate concentration of ABTS dissolved in $100 \mathrm{mM}$ buffer (citrate/phosphate, $\mathrm{pH} 4.0$ for ThLc and phosphate, $\mathrm{pH} 7.4$ for $\mathrm{MvBOx}$ ) was used in order to ensure a measurable linear rate for the first $30 \mathrm{~s}$ after the addition of prepared enzyme. The concentrations of $\mathrm{O}_{2}$ were assumed to be 0.25 and 1.2 $\mathrm{mM}$ in air- and $\mathrm{O}_{2}$-saturated buffers, respectively. ${ }^{29}$

Electrode Preparation. As working electrodes, we used $\mathrm{Au}$ substrates manufactured in a Balzers UMS $500 \mathrm{P}$ system by the electron-beam deposition of $2000 \AA$ of $\mathrm{Au}$ on silicon(100) wafers (planar polycrystalline Au electrodes) that had been precoated with a 25-Å-thick titanium adhesion layer (Laboratory of Applied Physics,
Linköping University, Sweden) with a geometrical area of about 0.32 $\mathrm{cm}^{2}$. Prior to all measurements (AFM, ellipsometrical, and electrochemical), Au electrodes were cleaned with a series of $\mathrm{CV}$ scans at a $200 \mathrm{mV} \mathrm{s}^{-1}$ scan rate between 0 and $-1200 \mathrm{mV}$ versus NHE in $0.5 \mathrm{M}$ $\mathrm{NaOH}$, and they were then rinsed thoroughly with $\mathrm{H}_{2} \mathrm{O}$ and finally cleaned by a series of $\mathrm{CV}$ scans at a $200 \mathrm{mV} \mathrm{s}^{-1}$ scan rate between 0 and $+1900 \mathrm{mV}$ versus $\mathrm{NHE}$ in $0.5 \mathrm{M} \mathrm{H}_{2} \mathrm{SO}_{4}$.

Clean Au working electrodes were modified by a simple adsorption of ThLc and $\mathrm{MvBOx}$ on the electrode surface using dilute and concentrated solutions of MCOs at room temperature $\left(\sim 25{ }^{\circ} \mathrm{C}\right)$. Specifically, for physisorption, ThLc and $\mathrm{MvBOx}$ in $50 \mathrm{mM}$ phosphate buffers with $\mathrm{pH}$ values varying from 6.0 up to 7.5 were used, and the enzyme concentration in the bulk solution varied from 0.125 to $4.0 \mathrm{mg}$ $\mathrm{mL}^{-1}$. For electrochemical and atomic force microscopy studies, a drop of solution containing different concentrations of enzymes was evenly deposited on top of the electrodes, adsorption was allowed to occur, and after 15 min the electrode was carefully rinsed with $\mathrm{H}_{2} \mathrm{O}$. A cuvette with a total volume of $4 \mathrm{~mL}$ was used (vide infra) in the ellipsometric measurements. It should be emphasized that electrodes did not dry out at any time during modification and investigations.

$\mathrm{Au}$ electrodes were connected to a potentiostate using Au-plated alligator clips (model 3289-2) from Pomona Electronics (Everett, WA, USA). The working areas of Au electrodes were determined by direct precise geometric measurements, and the area was also controlled electrochemically.

Electrochemistry. Cyclic voltammetry and chronoamperometry were performed in an electrochemical cell with a volume of $30 \mathrm{~mL}$ containing a saturated calomel reference electrode ( $242 \mathrm{mV}$ vs. NHE) and a platinum mesh counter electrode using a PGSTAT12 potentiostat/galvanostat from Metrohm Autolab B.V. (Utrecht, The Netherlands). As supporting electrolytes, a $100 \mathrm{mM}$ citrate/phosphate buffer solution at $\mathrm{pH} 4.0$ and a $100 \mathrm{mM}$ phosphate buffer solution at $\mathrm{pH} 7.4$ were used for measurements with ThLc- and $\mathrm{MvBOx}$-modified $\mathrm{Au}$ electrodes ( $\mathrm{ThLc} / \mathrm{Au}$ and $\mathrm{MvBOx} / \mathrm{Au}$ ), respectively. Electrochemical experiments were performed at $25{ }^{\circ} \mathrm{C}$. All potentials in the present work are given versus NHE.

Ellipsometry Measurements. The adsorption of $T h \mathrm{Lc}$ and $\mathrm{MvBOx}$ onto bare $\mathrm{Au}$ was studied in situ by means of null ellipsometry, which measures changes in the polarization of light reflected by a surface (the sample). A thin-film automated ellipsometer (type 43 603-200E, Rudolph Research, Fairfield, NJ, USA) equipped with a xenon arc lamp with a fixed angle of incidence $\left(67.96^{\circ}\right)$ was used. Light was detected at a wavelength of $442.9 \mathrm{~nm}$ employing an interference filter with ultraviolet and infrared blocking (MellesGriot, Netherlands). The $\mathrm{Au}$ surface was vertically mounted in a glass trapezoid cuvette (Hellma, Germany) containing $4 \mathrm{~mL}$ of solution, which was thermostated at $25^{\circ} \mathrm{C}$ and stirred using a magnetic stirrer with a rotational speed of $325 \mathrm{rpm}$. The changes in ellipsometric angles were recorded in situ every $15 \mathrm{~s}$. To determine the refractive index of the Au surface, a four-zone surface calibration in buffer solution was carried out prior to each measurement. When enzymes were to be adsorbed on the electrochemically cleaned Au surface (vide supra), first a stable baseline acquisition was done and then enzyme from the stock solution was added to the cuvette to a final volume of 4 $\mathrm{mL}$. The formation of protein films was monitored for $60 \mathrm{~min}$, followed by rinsing with enzyme-free buffer solution for $5 \mathrm{~min}$. From ellipsometric data, the protein layer thickness $(d$, in $\AA$ ) and the adsorbed amount per unit area $\left(\Gamma\right.$, in $\left.\mathrm{mg} \mathrm{m}^{-2}\right)$ were calculated by assuming a three-layer model ( $\mathrm{Au}$-enzyme layer-buffer solution) and using a value of $0.18 \mathrm{~mL} \mathrm{~g}^{-1}$ as the refractive index increment with respect to the change in protein concentration $(\mathrm{d} n / \mathrm{d} c) .{ }^{30}$ As an evaluation of the ellipsometric data, the refractive index can be either calculated $^{31}$ or assumed. Because the determination of the thickness of an adsorbed layer is not straightforward at low coverage, ${ }^{32,33}$ ellipsometry results obtained in this work were evaluated using both procedures. In doing so, the index was fitted according to the method described by McCrackin and co-workers. ${ }^{31}$ When assuming the refractive index, two values were taken into account: one based on our own work $(n=1.65)^{12}$ and another based on previously reported results $n=1.45 .^{34}$ Because of the complexity in evaluating the 
thicknesses of thin protein layers on $\mathrm{Au}$, as discussed further in the Results and Discussion section, we evaluated the trends (differences between conditions and enzymes) in thickness rather than the absolute values.

Atomic Force Microscopy. AFM images of $\mathrm{Au}$ surfaces were obtained using a commercial setup equipped with a liquid cell (MultiMode 8 SPM with a NanoScope V control unit, Bruker AXS). The samples were visualized in water at room temperature by operating the AFM in both tapping and in peak force tapping (PFT) modes. In tapping mode, the cantilever is oscillated at its free resonance frequency, and the tip-sample distance is adjusted during scanning so that the amplitude of the oscillation is kept constant. In this case, Au-coated cantilevers with a nominal spring constant of 0.03 $\mathrm{N} \mathrm{m}^{-1}$, a resonance frequency in air of $37 \mathrm{kHz}$, and a nominal tip radius in the $30-40 \mathrm{~nm}$ range (Biolever A, Olympus, Tokyo, Japan) were employed. In PFT mode, force curves are constantly recorded at a constant rate equal to $2 \mathrm{kHz}$. In this mode, the maximum load exerted on the sample is constantly and automatically minimized. When operating in PFT mode, triangular silicon nitride cantilevers with a nominal spring constant of $0.7 \mathrm{~N} \mathrm{~m}^{-1}$, a resonance frequency in air of $150 \mathrm{kHz}$, and a nominal tip radius of $20 \mathrm{~nm}$ were employed (ScanAsyst-Fluid, Bruker AXS). Analysis and processing of AFM images was performed with WSxM software. ${ }^{35}$ Standard image processing consisted of plane subtraction and/or equalization.

The AFM size of adsorbed molecules is given as mean and standard deviation values calculated by averaging the height measured in AFM topography images for at least 20 molecules. It is also important to note that all samples (electrodes) were placed in the AFM liquid cell immediately after electrochemical cleaning and biomodification without letting them dry at any moment.

\section{RESULTS AND DISCUSSION}

First, the MCOs were physisorbed on bare Au surfaces. Because both enzyme preparations were stored in $10 \mathrm{mM}$ phosphate buffer at pH 6.5 (vide supra), phosphate buffer was also used for their immobilization on $\mathrm{Au}$ surfaces in order to avoid additional manipulations (e.g., dialysis or chromatography steps). However, the phosphate concentration was increased from 10 to $50 \mathrm{mM}$ in order to adjust the $\mathrm{pH}$ during the dilution of the stock solutions properly. Different $\mathrm{pH}$ values of phosphate buffers used for the proteins' physisorption (6.07.5) reflect different $\mathrm{pH}$ dependences of the activity and stability of the different MCOs. Specifically, ThLc is very active but simultaneously quite unstable in acidic solutions, whereas it is very stable but inactive in neutral solutions. ${ }^{36}$ Contrary to ThLc, $M v \mathrm{BOx}$ is both active and stable in neutral solutions, ${ }^{37}$ whereas well-pronounced irreversible deactivation of the enzyme is known to occur in acidic media. ${ }^{38}$ Thus, for $\mathrm{M} v \mathrm{BO}$ xhysisorption $50 \mathrm{mM}$ phosphate buffer at $\mathrm{pH} 7.4$ was used, whereas the $\mathrm{pH}$ of the buffer used for $\mathrm{ThLc}$ adsorption was decreased to 6.0. Under these conditions, significant activity of the enzyme could still be registered without fast enzyme deactivation. For comparison, the physisorption of both MCOs was also performed from an identical solution, viz., $50 \mathrm{mM}$ phosphate buffer at $\mathrm{pH} 7.5$ (vide infra)). Both unmodified and modified electrodes, viz., bare $\mathrm{Au}, \mathrm{ThLc} / \mathrm{Au}$, and $M v \mathrm{BOx} / \mathrm{Au}$, were investigated by means of $\mathrm{AFM}$ as described below.

Atomic Force Microscopy Studies. As control measurements, evaporated $\mathrm{Au}$ surfaces that were electrochemically cleaned were imaged in water by operating the AFM in both the PFT and tapping modes (Figure 1a,b, respectively). Clean $\mathrm{Au}$ exhibited a granular surface, in accordance with previous reports. ${ }^{39}$ The grains exhibited lateral dimensions in the range of $50-200 \mathrm{~nm}$, with typical heights of about 10-15 nm resulting in a roughness factor of the Au surface $(f)$ of about
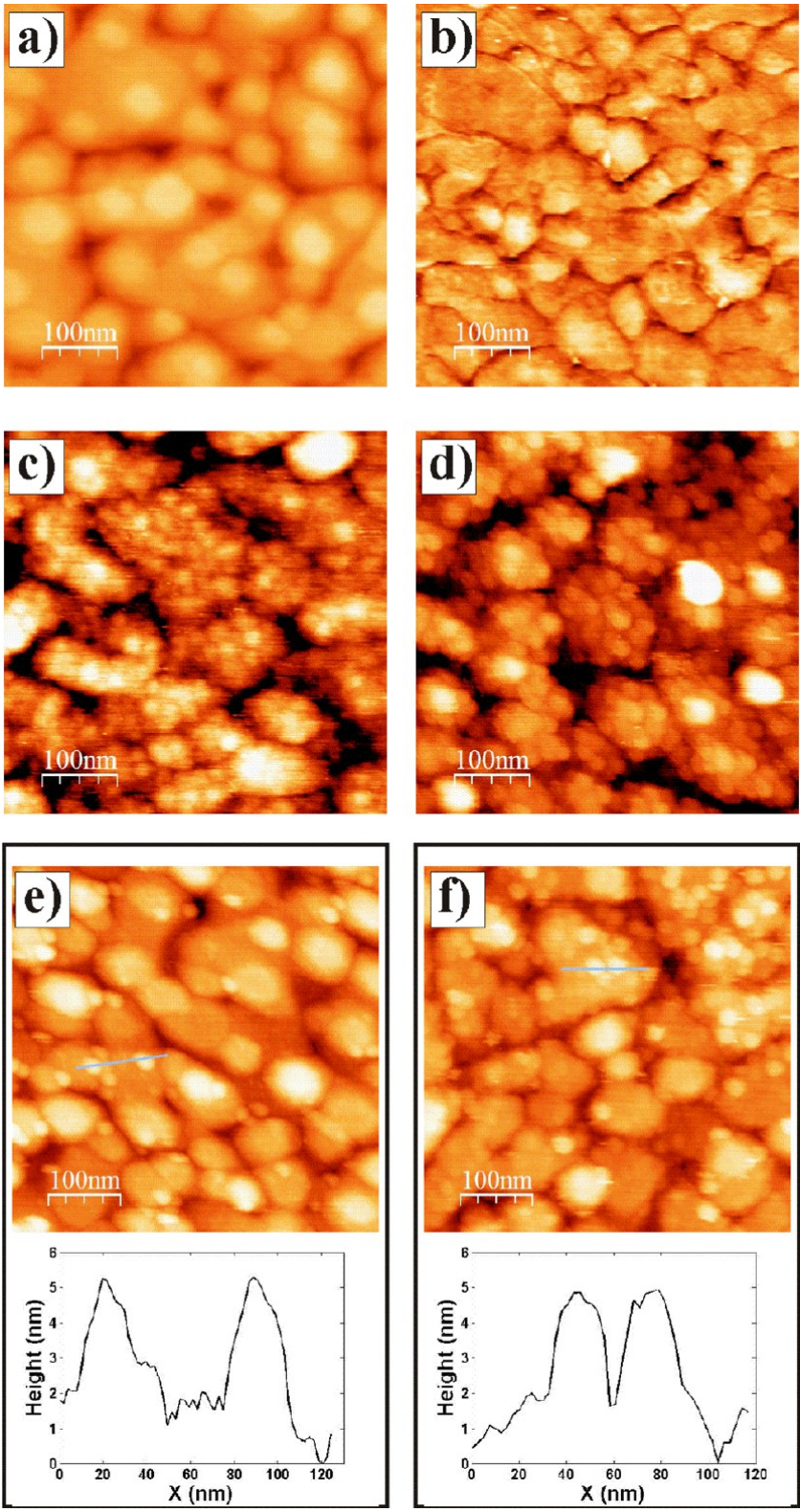

Figure 1. (a, b) AFM images of clean evaporated Au surfaces obtained in a water environment by operating the AFM in PFT mode and in tapping mode, respectively (color height scale $25 \mathrm{~nm}$ ). (c, d) Topography images of Au surfaces obtained with a high surface coverage of ThLc (tapping mode) and $\mathrm{MvBOx}$ (PFT mode), respectively (color height scale $12 \mathrm{~nm}$ ). In these samples, enzyme solutions with concentrations equal to $4.0 \mathrm{mg} \mathrm{mL}^{-1}$ in $50 \mathrm{mM}$ phosphate buffers, at $\mathrm{pH} 6.0$ and 7.4, in the case of ThLc and $M v \mathrm{BOx}$, respectively, were used for protein immobilization on Au surfaces. (e, f) Topography images obtained by operating the AFM in PFT mode and highlighted height profiles for the low surface coverage of ThLc and $M v \mathrm{BOx}$, respectively (color height scale $14 \mathrm{~nm}$ ). In these samples, enzyme solutions with concentrations equal to 0.125 and $0.25 \mathrm{mg}$ $\mathrm{mL}^{-1}$ in $50 \mathrm{mM}$ phosphate buffer at $\mathrm{pH} 6.0$ and 7.4, in the case of ThLc and $\mathrm{MvBOx}$, respectively, were used for protein immobilization on Au surfaces.

1.3. Thus, from AFM studies, the microscopic (real) $\mathrm{Au}$ electrode area $\left(A_{\text {real }}\right)$ was 1.3 times higher than the geometric (2D projected $)$ one $\left(A_{\text {geom; }}\right.$ see additional details concerning the electrode areas in SI). However, it is important to note that this value may be an underestimation because AFM would not 
be sensitive to roughness lower than the curvature of the tip. It should also be mentioned that AFM operation in tapping mode provided better lateral resolution than did the PFT technique.

MCOs were directly adsorbed on bare polycrystalline $\mathrm{Au}$ electrodes using highly concentrated enzyme preparations. A bulk enzyme concentration of $4 \mathrm{mg} \mathrm{mL}^{-1}$ was chosen, a value similar to those used in previous studies.,11,12 The MCOmodified Au surfaces were imaged by operating the AFM in both tapping and PFT modes (Figure 1c,d). A granular structure similar to that of clean $\mathrm{Au}$ was found for these surfaces. However, the Au grains were not smooth any longer; they seemed to be almost completely covered by globular features with average lateral dimensions of ca. $20 \mathrm{~nm}$. Although this width is higher than that expected for single ThLc and $M v \mathrm{BOx}$ molecules (4-6 nm; see additional details concerning enzyme structures and sizes in SI), it is well known that the visualization of features smaller than the AFM tip results in width values similar to those of the tip (ca. $20 \mathrm{~nm}$ ) resulting from tip dilation effects, ${ }^{40}$ with this being the most probable case in our experiments. Thus, it is likely that the topography images show the convolution of the AFM tip and the molecules protruding from the surface. Nevertheless, it is reasonable to assume (i) from the homogeneity of the samples and (ii) from the fact that the images do not show substrate zones without molecules that in both samples full coverage was obtained.

ThLc and $\mathrm{MvBOx}$ were also adsorbed on Au electrodes using dilute enzyme solutions (i.e., 0.125 and $0.25 \mathrm{mg} \mathrm{mL}^{-1}$, respectively) in order to obtain AFM images of the submonolayer coverage of the Au surface, from where the dimensions of single immobilized enzymes could be determined. AFM images of these samples obtained by operating in the PFT mode are shown in Figure 1e,f. Both samples showed isolated globular features on top of the wider $\mathrm{Au}$ grains.

These features exhibited similar lateral (ca. $20 \mathrm{~nm}$ ) and vertical dimensions, $2.9 \pm 0.6$ and $3.0 \pm 0.8 \mathrm{~nm}$ for $T h \mathrm{Lc}$ and $\mathrm{M} v \mathrm{BOx}$ samples, respectively. As in the case of fully covered samples, the molecules exhibiting larger lateral dimensions than those expected for single molecules can be attributed to tip dilation effects. ${ }^{40}$

Moreover, both types of molecules exhibited a similar height, which was lower than those expected for both $T h \mathrm{Lc}$ and $\mathrm{M} v \mathrm{BOx}$ molecules (4-6 nm, SI). However, this is also expected for single adsorbed proteins because the AFM-determined height of soft biological molecules is usually smaller than its nominal value as a result of tip compression effects. ${ }^{41}$ Thus, it is reasonable to associate the AFM-determined height of the globular features visualized on top of the Au grains with that of individual protein molecules.

It is important to emphasize that no desorption of either protein from the electrode surface was registered by AFM when modified electrodes were kept in buffer solutions with different $\mathrm{pH}$ values ( $\mathrm{pH} 4$ and 7.4, i.e., both very close and very far from the $\mathrm{pI}$ values of ThLc and $M v \mathrm{BOx}$; SI) for $1 \mathrm{~h}$, indicating that the adsorption of both $\mathrm{MvBOx}$ and $\mathrm{ThLc}$ on $\mathrm{Au}$ has an irreversible character.

The quantitative AFM analysis of $\mathrm{MCO} / \mathrm{Au}$ surfaces is summarized in Table 1 and Supporting Information Table S1, where height values for both MCOs (ThLc and $M v \mathrm{BOx}$ ) are presented.

To complement the AFM results, additional ellipsometry studies of $\mathrm{Au}$ electrodes were carried out, as described below.
Table 1. Au Surface Coverage with $\operatorname{MCOs}(\Gamma)$ and Thickness of Enzymatic Layers (Enzyme Height, $d$ ) on $\mathrm{Au}^{a, b}$

\begin{tabular}{lllll} 
MCO & \multicolumn{1}{c}{$\Gamma$ and $d$} & theoretical & AFM & ellipsometry \\
ThLc & $\Gamma$, pmol cm & & \\
& $d, \AA$ & $3.95-8.23$ & n.d. & $\sim 1.7$ \\
MvBOx & $\Gamma$, pmol cm & $45-65$ & 29 & 7 \\
& $d, \AA$ & $4.63-10.42$ & n.d. & $\sim 4.8$ \\
& $40-60$ & 30 & 17
\end{tabular}

${ }^{a}$ Ellipsometry data were calculated using a fixed value for $n=1.65$. The enzyme solutions with concentrations equal to 0.125 and $0.25 \mathrm{mg}$ $\mathrm{mL}^{-1}$ in the case of $T h \mathrm{Lc}$ and $\mathrm{MvBOx}$, respectively, were used for protein immobilization on Au surfaces. ${ }^{b}$ n.d. - not determined.

Ellipsometry Studies. Ellipsometric measurements can be used for the determination of the refractive index and thickness of thin films by using, for example, the Cuypers ${ }^{32}$ or de Feiter ${ }^{30}$ formula to determine the adsorbed mass. The accuracy of mass determination has been shown to be more accurate that the determination of refractive indices or thicknesses, particularly at low adsorbed mass. ${ }^{33}$ Furthermore, refractive indices can be calculated $^{31}$ or assumed. As shown in some previous work, ${ }^{32,33}$ assuming a plane parallel model for the film, the refractive index and thickness co-vary, so an overestimation of one results in an underestimation of the other. In the calculation of mass, this will be compensated for, thus resulting in values with much higher reliability. Therefore, in the present work ellipsometry is mainly used as a mass sensing tool, whereas AFM is used as an enzyme-height-determining technique (vide supra).

The adsorption of both enzymes onto the electrochemically cleaned $\mathrm{Au}$ surfaces was followed by means of ellipsometry, as shown in Figure 2, where the time evolution of the adsorbed amount of protein $(\Gamma)$ at the electrode with $A_{\text {geom }}=0.32 \mathrm{~cm}^{2}$ and the thickness of the enzymatic layers $(d)$ are presented. Taking into account that the $\mathrm{pI}$ of both redox enzymes is close to 4 (see additional details concerning basic biochemical properties of the MCOs in SI), one can conclude that both proteins were negatively charged during all immobilization processes. It is important to emphasize that no desorption of proteins from the electrode surface was registered by ellipsometry measurements when rinsing with enzyme-free buffer solutions with different $\mathrm{pH}$ values ( $\mathrm{pH} 4$ and 7.5, i.e., both very close and very far from the $\mathrm{pI}$ values of both $T h L c$ and $M v B O x$ ) after modification (Figure 2), confirming that the adsorption of both $\mathrm{MvBOx}$ and $\mathrm{ThLc}$ on Au has irreversible character in the experimentally relevant time frame.

Much higher $\Gamma$ values were obtained for $M v \mathrm{BOx}, \Gamma=2.9 \pm$ $0.1 \mathrm{mg} \mathrm{m}^{-2}\left(\sim 4.8 \mathrm{pmol} \mathrm{cm}^{-2}\right.$; see calculation details in SI), than for $T h \mathrm{Lc}, \Gamma=1.6 \pm 0.1 \mathrm{mg} \mathrm{m}^{-2}\left(\sim 1.7 \mathrm{pmol} \mathrm{cm}{ }^{-2}\right)$ (Figure 2a). Because two different concentrations of MCOs were used during protein immobilization (in analogy with the AFM studies, solutions of ThLc and $M v \mathrm{BOx}$ with concentrations of 0.125 and $0.25 \mathrm{mg} \mathrm{mL}^{-1}$, respectively, were used), the possible dependence of $\Gamma$ values on the bulk enzyme concentration used for the adsorption procedure was evaluated (SI). As can be seen from the results presented in SI, changes in ThLc bulk concentrations from 0.125 to $4.0 \mathrm{mg} \mathrm{mL}^{-1}$ resulted in increased $\Gamma$ from 1.2 to $2.2 \mathrm{mg} \mathrm{m}^{-2}$ (Supporting Figure S4). However, even when the bulk concentration of ThLc used for the absorption was 16 times higher than that of $M v \mathrm{BOx}$ (4.0 vs $0.25 \mathrm{mg} \mathrm{mL}^{-1}$ ), a lower $\Gamma$ value for ThLc was still obtained (cf. $2.2 \mathrm{mg} \mathrm{m}^{-2}$ for $T h \mathrm{Lc}$ and $2.9 \mathrm{mg} \mathrm{m}^{-2}$ for $M v \mathrm{BOx}$ ). The determination of thicknesses of thin (submonolayer) films of proteins on solid supports and specifically on $\mathrm{Au}$ (see below) is 

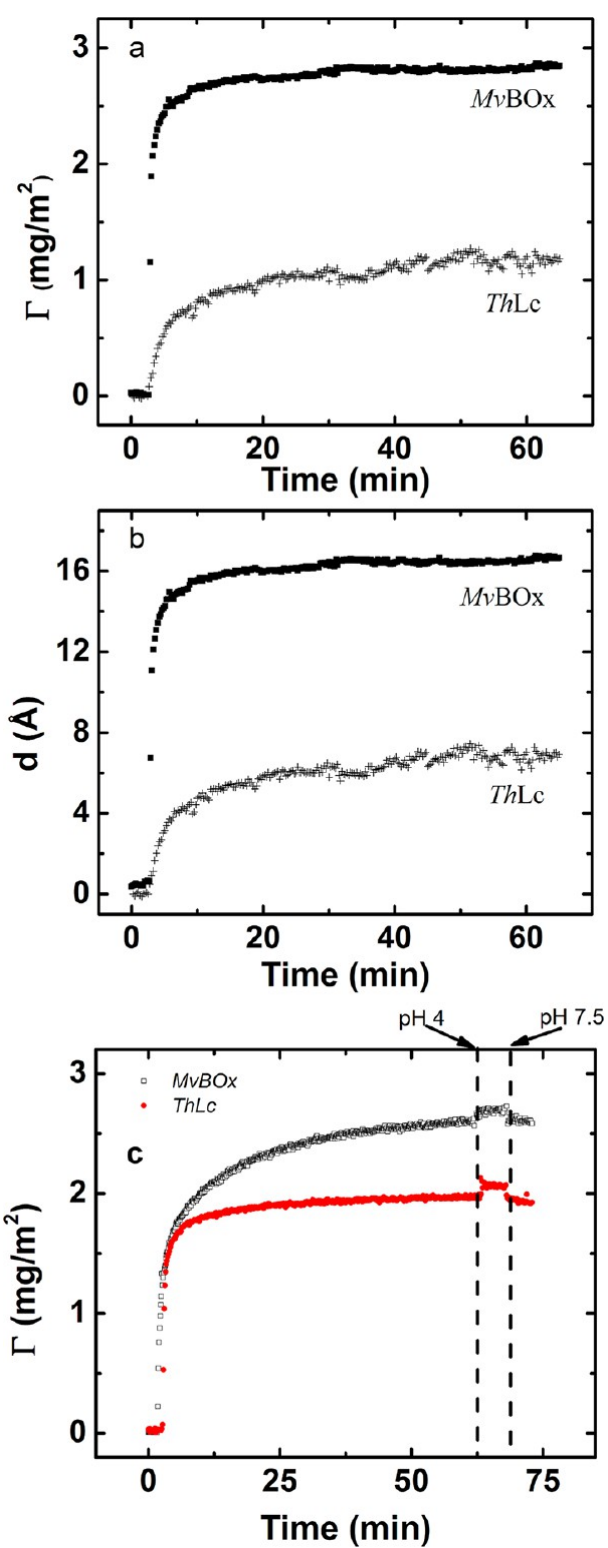

Figure 2. Ellipsometric data of $\mathrm{MCO}$ adsorption on bare Au surfaces. Adsorption onto the bare polycrystalline $\mathrm{Au}$ surface of $\mathrm{MvBOx}$ and ThLc followed in situ by means of null ellipsometry. Enzyme solutions with concentrations equal to 0.125 and $0.25 \mathrm{mg} \mathrm{mL}^{-1}$ in $50 \mathrm{mM}$ phosphate buffers at $\mathrm{pH} 6.0$ and 7.4 in the case of ThLc and $\mathrm{MvBOx}$, respectively (a, b), or $0.125 \mathrm{mg} \mathrm{mL}^{-1}$ in $50 \mathrm{mM}$ phosphate buffers at $\mathrm{pH} 7.5$ for both MCOs (c) were used for protein immobilization on $\mathrm{Au}$ surfaces. The thickness was calculated by assuming a constant refractive index of 1.65 .

not straightforward for a number of reasons. First, fitting to the model (plane parallel homogeneous film) becomes less accurate at low adsorbed mass. ${ }^{33}$ Second, at low coverage the modeling of the layer as a plane parallel homogeneous film will result in an average thickness that will be lower than the real dimensions of the protein. Finally, Au has been shown to interact strongly with proteins; therefore, sophisticated modeling (e.g., assuming a mixed protein/Au layer with intermediate optical properties between the surface and the protein) has been proposed in order to obtain realistic values. ${ }^{42}$ Therefore, our evaluations were carried out using two different approaches: (1) by calculating the refractive index ${ }^{31}$ and (2) by the assumption of two different refractive indices (vide supra).
It is important to point out that because of these uncertainties absolute values of thickness should not be overinterpreted; rather, the focus should be on the differences observed between conditions and enzymes.

The thicknesses of the enzymatic layers $(d)$ calculated from the ellipsometric measurements had very low values (Figure $2 \mathrm{~b})$, viz., $1.7 \pm 0.1$ and $0.7 \pm 0.1 \mathrm{~nm}$ for $\mathrm{MvBOx}$ and ThLc, respectively. In the case of a very high $T h \mathrm{Lc}$ concentration during enzyme adsorption $\left(4 \mathrm{mg} \mathrm{mL}^{-1}\right), d=1.3 \pm 0.1 \mathrm{~nm}$ was obtained (i.e., it is 6-10 times lower than the height of the native enzyme (Table 1)). Indeed, when an $n$ value for the refractive index equal to 1.45 instead of 1.65 was used for calculations, significantly higher $d$ and slightly lower $\Gamma$ values were obtained (Supporting Information Figure S5), and $d$ values from AFM and ellipsometry studies almost coincided (Supporting InformationTable S1).

In summary, the thickness of the enzyme layer decreases in the order $d_{M v \text { BOx }}\left(0.25 \mathrm{mg} \mathrm{mL}^{-1}\right)>d_{\text {ThLc }}\left(4 \mathrm{mg} \mathrm{mL}^{-1}\right)>d_{\text {ThLc }}$ $\left(0.125 \mathrm{mg} \mathrm{mL}^{-1}\right)$ irrespective of the method used for evaluation. This also implies that the obtained results are not a modeling-dependent artifact.

The quantitative analysis of ellipsometrical results is compiled in Table 1 and Supporting Information Table S1, where $\Gamma$ and $d$ values for both ThLc and $M v \mathrm{BOx}$ molecules are presented. To conclude, AFM and ellipsometry studies confirmed a submonolayer coverage of both $T h \mathrm{Lc}$ and $\mathrm{M} v \mathrm{BOx}$ on the $\mathrm{Au}$ surface when dilute preparations of the enzymes were used for modification. Both bare Au (control studies) and $\mathrm{MCO} / \mathrm{Au}$ electrodes, investigated by AFM and ellipsometry, were also electrochemically characterized, as described below.

Electrochemical Investigations. First, an average $f$ value for bare $\mathrm{Au}$ electrodes was calculated during electrochemical cleaning. Additional details concerning the calculations as well as some experimental results are described in the SI (Supporting Figure S6). The obtained result $(f=1.6)$ correlates well with calculations of real surface areas based on AFM studies of bare Au electrodes (vide supra).

Second, the electrodes were modified with $T h \mathrm{Lc}$ or $M v \mathrm{BO}$ and placed in air-saturated buffers, and cyclic voltammograms (CVs) of modified Au electrodes were recorded. The catalytic current related to the bioelectroreduction of $\mathrm{O}_{2}$ was clearly visible only for $\mathrm{MvBOx} / \mathrm{Au}$ electrodes (Figure 3a, Supporting Information Figures S7-S8), whereas adsorbed ThLc was bioelectrocatalytically inactive (Figure 3a, Supporting Information Figures S11-S12). When electrochemical measurements of $\mathrm{MvBOx} / \mathrm{Au}$ were performed in the air-saturated buffer, a steady-state bioelectrocatalytic response was obtained with an onset potential of $\mathrm{O}_{2}$ bioreduction at about $0.7 \mathrm{~V}$ (Figure 3a, curve 2), coinciding with the proposed $E_{\mathrm{T} 1}$ value of the enzyme. $^{43}$

Taking into account motionless electrodes and unstirred solutions used in our studies, the shape of the CV (an almost steady-state potential current curve at high overpotentials) and the observed slight dependence of the biocatalytic current on solution stirring show evidence of $\mathrm{O}_{2}$ mass-transfer limitations (additional details in SI). When increasing the $\mathrm{O}_{2}$ concentration from 0.25 to $1.2 \mathrm{mM}$, the maximal current density $\left(j_{\max }\right)$ corresponding to bioelectrocatalytic $\mathrm{O}_{2}$ reduction increased only by a factor of 3 (i.e., from $19 \mu \mathrm{A} \mathrm{cm} \mathrm{cm}^{-2}$ in air-saturated buffer to $53 \mu \mathrm{A} \mathrm{cm}$ cm $^{-2}$ in $\mathrm{O}_{2}$-saturated buffer (Supporting Information Figure S7), also suggesting $\mathrm{O}_{2}$ diffusion limitations (SI). 

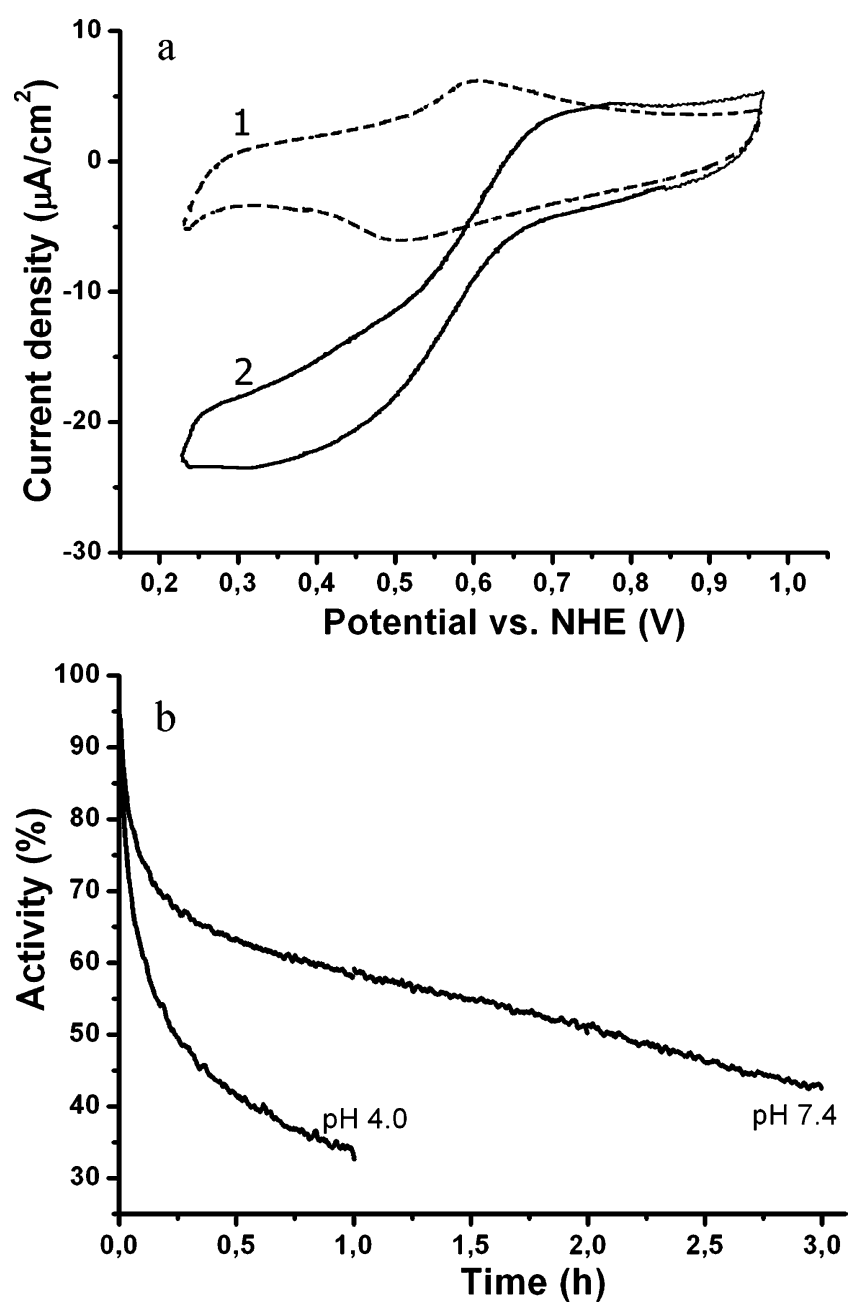

Figure 3. Electrochemical investigations of MCO-modified $\mathrm{Au}$ electrodes. (a) $\mathrm{CVs}$ of MCO-modified $\mathrm{Au}$ electrodes: ThLc-Au (curve 1) and $\mathrm{MvBOx}-\mathrm{Au}$ (curve 2). Enzyme solutions with concentrations equal to 0.125 and $0.25 \mathrm{mg} \mathrm{mL}^{-1}$ in $50 \mathrm{mM}$ phosphate buffers, $\mathrm{pH} 6.0$ and 7.4, in the case of ThLc and $\mathrm{MvBOx}$, respectively, were used during the biomodification of $\mathrm{Au}$ surfaces. Measurement conditions: $100 \mathrm{mM}$ buffers (citrate/phosphate $\mathrm{pH} 4.0$ for ThLc and phosphate; $\mathrm{pH} 7.4$ for $\mathrm{MvBOx}$ ); scan rate, $20 \mathrm{mV} \mathrm{s}^{-1}$; second cycle. (b) Chronoamperometric responses from $\mathrm{MvBOx-modified} \mathrm{Au}$ electrodes recorded at a $+400 \mathrm{mV}$ applied potential. Initial $j_{\text {cat }}$ values were 18.3 and $7.6 \mu \mathrm{A} \mathrm{cm}^{-2}$ at $\mathrm{pH} 4.0$ and 7.4, respectively. Conditions: $100 \mathrm{mM}$ citrate/phosphate buffer at $\mathrm{pH} 4.0$ and $100 \mathrm{mM}$ phosphate buffer at $\mathrm{pH}$ 7.4.

The apparent biocatalytic constant $\left(k_{\text {cat }}^{\text {app }}\right)$ for adsorbed $M v \mathrm{BOx}$ was calculated to be $54 \mathrm{~s}^{-1}$ (calculation details can be found in the SI), taking into account that the $\Gamma$ value for $\mathrm{M} v \mathrm{BOx}$ on Au equals $4.8 \mathrm{pmol} \mathrm{cm}{ }^{-2}$ (Table 1 and Supporting Information Table S1) from ellipsometry studies. It is worthwhile to mention that voltammetric data with a low enzyme concentration $\left(0.25 \mathrm{mg} \mathrm{mL} \mathrm{mL}^{-1}\right)$ used for electrode modification were taken into account during calculations in order to avoid situations in which the formation of multilayers could be suggested (vide supra).

When $\mathrm{F}^{-}$, a known efficient inhibitor of active MCO, was added to the air-saturated buffer solution at a $100 \mathrm{mM}$ concentration, the electrocatalytic current from $\mathrm{MvBOx} / \mathrm{Au}$ electrodes vanished (Supporting Information Figure S7), confirming the bioelectrocatalytic origin of the obtained currents.

The operational stability of $\mathrm{MvBOx} / \mathrm{Au}$ electrodes was investigated in both acidic and neutral solutions (Figure $3 \mathrm{~b}$ ). The half-inactivation time for $\mathrm{MvBOx} / \mathrm{Au}$ electrodes was calculated to be 0.25 and $2.5 \mathrm{~h}$ at $\mathrm{pH} 4.0$ and 7.4, respectively. In other words, after $3 \mathrm{~h}$ of biocathode operation $k_{\mathrm{cat}}^{\mathrm{app}}$ for the adsorbed $\mathrm{MvBOx}$ decreased to $23 \mathrm{~s}^{-1}$ in solution at $\mathrm{pH} 7.4$, whereas under acidic conditions the enzyme was completely inactivated. Fast deactivation of the adsorbed enzyme under acidic conditions is a widely held notion. Indeed, MCO preparations (both $\mathrm{BOx}$ and $\mathrm{Lc}$ ) are usually stored in weak buffers with neutral $\mathrm{pH}$ values $(10 \mathrm{mM}$ phosphate buffer at $\mathrm{pH}$ 6.5 in our studies, vide supra). Because both AFM and ellipsometry studies clearly indicated that the adsorption of $\mathrm{M} v \mathrm{BOx}$ and ThLc on Au has irreversible character, one can conclude that the time decay of the $k_{\mathrm{cat}}^{\mathrm{app}}$ is due to the gradual deactivation of the enzyme but not to its desorption from the electrode surface.

As already mentioned, contrary to $\mathrm{MvBOx} / \mathrm{Au}, \mathrm{Au}$ electrodes modified with $T h \mathrm{Lc}$ were bioelectrocatalytically inactive. Significant increases in enzyme concentration used for modification (Supporting Information Figure S11) and an increase in $\mathrm{O}_{2}$ content in the buffer (Supporting Information Figure S12) did not result in the appearance of even slight bioelectrocatalytic currents from $\mathrm{ThLc} / \mathrm{Au}$ electrodes.

Enzymatic Assay. The observed $k_{\text {cat }}$ values of ThLc and $M v \mathrm{BOx}$ toward ABTS in homogeneous reactions were calculated to be 205 and $58 \mathrm{~s}^{-1}$ at $\mathrm{pH} 4.0$ and 7.4, respectively (vide supra). To determine the activity of both enzymes in heterogeneous systems $(\mathrm{MCO} / \mathrm{Au})$ using $\mathrm{ABTS}$ as an electrode donor (qualitative enzymatic assay), a few hundred microliters of air-saturated buffers $(100 \mathrm{mM}$ citrate-phosphate at $\mathrm{pH} 4.0$ for $\mathrm{ThLc} / \mathrm{Au}, 100 \mathrm{mM}$ phosphate at $\mathrm{pH} 7.4$ for $\mathrm{M} v \mathrm{BOx} / \mathrm{Au}$, and both buffers for bare $\mathrm{Au}$ electrodes) containing the substrate of the enzymes (i.e., $5 \mathrm{mM} \mathrm{ABTS}$ ) was dropped on top of the Au electrodes, both unmodified as well as modified with ThLc and $M v B O x$, as illustrated in Figure 4.

A clear blue color was developed in just a few minutes, when $\mathrm{M} v \mathrm{BOx} / \mathrm{Au}$ wafers were used, whereas no biocatalytic reaction of ABTS oxidation was registered for $\mathrm{ThLc} / \mathrm{Au}$ or bare $\mathrm{Au}$ electrodes, even when incubated with the enzyme substrate for $1 \mathrm{~h}$ (Figure 4). Because no desorption of the enzyme was observed in our studies as described above, these measurements confirmed that adsorbed $\mathrm{MvBOx}$ was catalytically active whereas ThLc was completely deactivated after immobilization on bare Au surfaces.

General Discussion. The difference in coverage between the two MCOs is a puzzle, which obviously complicates the interpretation of the results. To the best of our knowledge, the hydrodynamic radii of $T h \mathrm{Lc}$ and $M v \mathrm{BO}$ are unknown. However, there is an investigation showing that the crystallographic size of an MCO (T. versicolor $\mathrm{Lc}$ ) and its hydrodynamic size are comparable. ${ }^{44}$ Thus, because of ThLc being larger than $M v B O x(S I)$, higher $\Gamma$ values are expected (in moles) when $\mathrm{BOx}$ is used for surface modification. However, the measured difference is too high to take into account only this simple explanation. Nevertheless, the experimental results described above give a positive answer to the first question specified in the Introduction concerning the bioelectrocatalytic reduction of $\mathrm{O}_{2}$ by MCOs directly adsorbed on polycrystalline bare planar $\mathrm{Au}$ electrodes. Specifically, well-pronounced bio(electro)- 


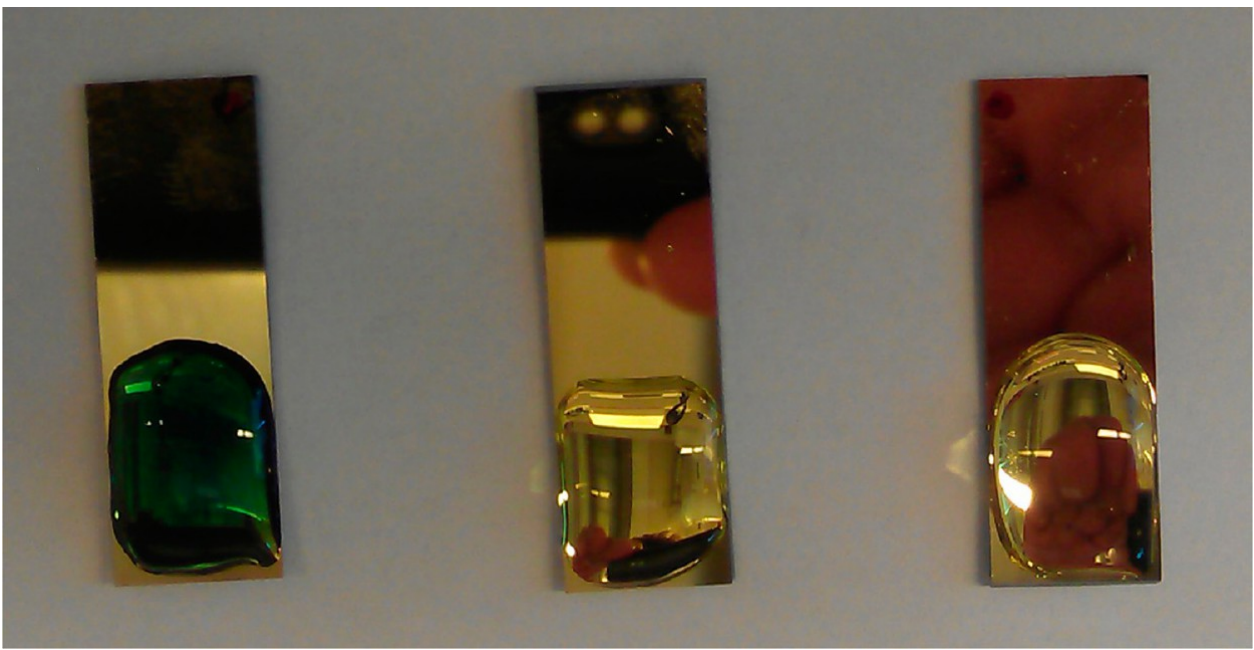

Figure 4. Photographs of polycrystalline Au electrodes with drops of $5 \mathrm{mM} \mathrm{ABTS}$ in buffers after $1 \mathrm{~h}$ of incubation. (Left) $\mathrm{MvBOx} / \mathrm{Au}$ electrode. (Middle) ThLc/Au electrode. (Right) Bare Au electrode (control). Enzyme solutions with concentration equal to $0.125 \mathrm{mg} \mathrm{mL}^{-11}$ in $50 \mathrm{mM}$ phosphate buffer at $\mathrm{pH} 6.0$ and 7.4, in the cases of ThLc and $\mathrm{MvBOx}$, respectively, were used during the modification of Au surfaces.

catalytic reactions of $\mathrm{O}_{2}$ reduction were registered on $\mathrm{MvBOx} /$ polycrystalline $\mathrm{Au}$ electrodes when they were electrochemically polarized (Figure 3) as well as when an electron donor was added to the solution (Figure 4).

The second question, viz., why in many previous attempts concerning $\mathrm{MCO} / \mathrm{Au}$ electrochemistry $\mathrm{O}_{2}$ bioelectroreduction was not registered, is also quite easy to answer. Because the well-pronounced bio(electro)catalytic reduction of $\mathrm{O}_{2}$ was never registered for $\mathrm{ThLc} / \mathrm{Au}$ electrodes in the present studies, neither when the electrodes were electrochemically polarized (Figure 3a, Supporting Figures S11-S12) nor when the electron donor was added directly to the solution (Figure 4), one can conclude that ThLc is completely deactivated on the bare polycrystalline planar $\mathrm{Au}$ surface. It is worthwhile to mention that bare carbon electrodes with adsorbed $\mathrm{ThLc}^{7}$ or nanostructured $\mathrm{Au}$ electrodes modified with the same enzyme $^{24,25}$ showed well-pronounced bioelectrocatalytic responses under similar conditions. Moreover, very high $k_{\text {cat }}^{\text {app }}$ values are usually calculated for ThLc adsorbed on modified (e.g., thiol-functionalized) Au surfaces $\left(\gg 100 \mathrm{~s}^{-1}\right.$ in refs 19 and 24). Contrary to $T h \mathrm{Lc} / \mathrm{Au}, \mathrm{MvBOx}$ immobilized on bare $\mathrm{Au}$ is still catalytically active for quite a long time, even if some deactivation of the enzyme definitely occurs (Figure $3 b$ ), and the rate of this process depends on the experimental conditions. Actually, the initially calculated $k_{\text {cat }}^{\text {app }}$ value for adsorbed $M v \mathrm{BOx}$ $\left(54 \mathrm{~s}^{-1}\right)$ is very close to the $k_{\text {cat }}$ value measured in a homogeneous assay $\left(58 \mathrm{~s}^{-1}\right)$. However, after $3 \mathrm{~h}$ of operation of $\mathrm{M} v \mathrm{BOx} / \mathrm{Au}$ biocathodes, the $k_{\text {cat }}^{\text {app }}$ value decreased to $23 \mathrm{~s}^{-1}$. However, it is difficult to compare $k_{\text {cat }}$ values obtained in homogeneous assays and DET-based bioelectrocatalysis because the limiting steps in homogeneous and heterogeneous systems could be different. For instance, while the oxidation of electron donors is known to be the limiting step during homogeneous assays (step 1 in Supporting Information Figure S2), intramolecular ET and the reduction of $\mathrm{O}_{2}$ by the trinuclear copper cluster are the limiting steps during heterogeneous BOx-based bioelectrocatalysis (steps 2 and 3 in Supporting Information Figure S2). ${ }^{37}$ However, the results from stability studies of $\mathrm{MvBOx} / \mathrm{Au}$ electrodes (Figure $3 \mathrm{~b}$ ), which showed very fast deactivation of the adsorbed enzyme especially in acidic buffers, also strongly support the idea that
ThLc was completely deactivated on the bare Au surface and that ThLc deactivation occurred at much higher rates than did $\mathrm{MvBOx}$. This is actually quite surprising considering the fact that ThLc is heavily glycosylated as compared to $M v \mathrm{BOx}$ (SI). On the one hand, there is a widely held notion that carbohydrates are responsible for the stabilization of proteins and deglycosylated enzymes have much lower operational stability than do glycosylated oxidoreductases. On the other hand, it has also recently been shown that the immobilization of deglycosylated redox enzymes results in their stabilization on the electrode surface whereas, as expected, they are unstable in solution. ${ }^{45,46}$ Thus, in all likelihood, glycosylation is not responsible for enzyme stabilization in the immobilized state.

As described in the Introduction, three main reasons for the absence of $\mathrm{O}_{2}$ bioelectroreduction on $\mathrm{MCO} / \mathrm{Au}$ exist in the literature: (1) enzyme deactivation, (2) the absence of heterogeneous ET, and (3) the formation of inactive forms of MCOs. Taking into account the experimental results presented herein, it can be concluded that the main reason for the absence of $\mathrm{O}_{2}$ bioelectroreduction in many previous attempts concerning $\mathrm{MCO} / \mathrm{Au}$ electrochemistry is the fast deactivation of the enzymes on bare Au surfaces. Even if the second and third reasons could be taken into account as possible explanations for the absence of DET-based bioelectrocatalysis (Figure 3, Supporting Information Figures S11S12), enzymatic assays in homogeneous and heterogeneous systems (Figure 4) clearly indicate that neither the absence of heterogeneous ET nor the formation of inactive (resting) forms of MCOs are responsible for the inertness of $\mathrm{ThLc} / \mathrm{Au}$. Specifically, in the presence of both enzyme substrates, viz., electron donor (ABTS) and electron acceptor $\left(\mathrm{O}_{2}\right)$, the biocatalytic oxidation of ABTS should occur even if DET between $T h \mathrm{Lc}$ and $\mathrm{Au}$ is not achieved. The biocatalytic oxidation of ABTS should also occur even if resting forms of ThLc are formed on bare Au surfaces. It is well known that resting forms (both the resting oxidized form ${ }^{2}$ and the resting partially reduced states ${ }^{27}$ ) in the presence of both substrates will be transformed into the native intermediate (i.e., the catalytically relevant form of $\mathrm{MCOs}^{2,47}$ ). Even though the rate of this transformation is very low (only $1 \mathrm{~s}^{-1}$ ), ${ }^{47} 3600 \mathrm{~s}$ experiments (as demonstrated in Figure 4) should be long 
enough to transfer all resting $T h \mathrm{Lc}$ molecules into the active enzyme.

It is also worthwhile to mention the very fast deactivation of $\mathrm{M} v \mathrm{BOx}$ on $\mathrm{Au}(111)^{17}$ as compared to that when adsorbed on polycrystalline $\mathrm{Au}$ (present study). It can be hypothesized that the protein is held much more tightly on $\mathrm{Au}(111)$, a highly ordered and smooth surface, compared to the situation where polycrystalline $\mathrm{Au}$ is used, resulting in a faster deactivation. The most difficult question to answer on a molecular level without serious speculation is why the fast deactivation of MCOs on a bare Au surface occurs. Although very low $d$ values compared to the height of the native enzymes were obtained for both $T h \mathrm{Lc}$ and $M v B O x$, this difference was still much higher for ThLc (Table 1). This indicates serious flattening of the enzyme on a bare Au surface. Specifically, the very low $d$ values (7-29 A, i.e., 1.5-9.3 times lower than the height of the native enzyme) registered in AFM experiments are also very strong evidence for ThLc deactivation on bare Au electrodes, in all likelihood being due to the enzyme flattening on the metal surface. By taking into account much higher $\Gamma$ values for $M v \mathrm{BOx}$ than for ThLc (Table 1 and Supporting Table S1), one can speculate that steric effects prevent $\mathrm{MvBOx}$ from spreading on the surface, thereby preventing their inactivation due to conformational changes.

\section{CONCLUSIONS}

For the first time, we provide mechanistic insight into the interfacial behavior and activity of MCOs on bare Au surfaces. The obtained experimental results show without doubt the efficient bioelectrocatalytic reduction of $\mathrm{O}_{2}$ at least by some MCOs (e.g., $M v \mathrm{BOx}$ ) directly adsorbed on a bare polycrystalline planar Au surface. Conformational changes of MCOs on the electrode are suggested to explain the observed experimental data (i.e., absence of bioelectrocatalysis for ThLc/Au electrodes) as well as the fast degradation of bioelectrocatalytic signals in the case of $M v \mathrm{BOx}$-based biocathodes. Comparison of the $k_{\mathrm{cat}}^{\text {app }}$ values in homogeneous and heterogeneous systems also confirms our suggestion concerning the inactivation of MCOs on bare polycrystalline planar Au surfaces. Taking into account AFM concerning the heights of adsorbed enzyme molecules as well as experimental results in the literature and the present studies concerning the very fast deactivation of $\mathrm{MvBOx}$ on highly ordered and smooth $\mathrm{Au}(111)$ compared to that on polycrystalline $\mathrm{Au}$, we suggest that the inactivation of MCOs on bare Au is, in all likelihood, due to the enzyme flattening on the metal surface.

\section{ASSOCIATED CONTENT}

\section{S Supporting Information}

Additional information about redox enzymes; AFM, ellipsometry, and electrochemical data; and the theoretical basis of electrochemical measurements and enzymatic assay results. This material is available free of charge via the Internet at http://pubs.acs.org.

\section{AUTHOR INFORMATION}

\section{Corresponding Author}

*E-mail: sergey.shleev@mah.se.

\section{Author Contributions}

S.S. and T.A. conceived and initiated the project. D.P., J.S., and A.B. performed electrochemical, AFM, and ellipsometry studies, respectively, and analyzed the data. All authors discussed the results and implications and commented on the work. The manuscript was written through the contributions of all authors, and all authors have given approval to the final version of the manuscript.

\section{Notes}

The authors declare no competing financial interest.

\section{ACKNOWLEDGMENTS}

We thank Dr. Olga V. Morozova (Institute of Biochemistry, Moscow, Russia) and Dr. Karolina Haberska (Malmö University, Malmö, Sweden) for the purification of $M v \mathrm{BOx}$ and some ellipsometry measurements with ThLc, respectively. This work has been financially supported by the Russian Foundation for Basic Research (research projects 12-04-33102 and 13-04-12083), the Gustaf Th. Ohlsson Foundation, and the Faculty of Health and Society, Malmö University, Sweden.

\section{ABBREVIATIONS}

$A_{\text {geom }}$ geometric electrode area; $\mathrm{AOx}$, ascorbate oxidase; $A_{\text {real }}$, microscopic (real) electrode area; AFM, atomic force microscopy; $\mathrm{Au}$, gold; $\mathrm{BOx}$, bilirubin oxidase; $\mathrm{Cp}$, ceruloplasmin; CVs, cyclic voltammograms; $d$, thicknesses of the enzymatic layer; DET, direct electron transfer; $E_{\mathrm{T} 1}$, redox potential of the $\mathrm{Cu}-\mathrm{T} 1$ site; $f$, roughness factor; $j_{\max }$, maximal bioelectrocatalytic current density; Lc, laccase; MCO, multicopper oxidase; $\mathrm{M} v \mathrm{BOx}$, Myrothecium verrucaria bilirubin oxidase; NHE, normal hydrogen electrode; PFT, peak force tapping mode; $q_{\text {real }}$ charge associated with the gold oxide reduction process; ThLc, Trametes hirsuta laccase; SI, supporting information; $\Gamma$, protein concentration on the electrode surface

\section{REFERENCES}

(1) Sakurai, T.; Kataoka, K. Basic and applied features of multicopper oxidases, $\mathrm{CueO}$, bilirubin oxidase, and laccase. Chem. Rec. 2007, 7, 220-229.

(2) Solomon, E. I.; Sundaram, U. M.; Machonkin, T. E. Multicopper oxidases and oxygenases. Chem. Rev. 1996, 96, 2563-2605.

(3) Berezin, I. V.; Bogdanovskaya, V. A.; Varfolomeev, S. D.; Tarasevich, M. R.; Yaropolov, A. I. Bioelectrocatalysis. Equilibrium oxygen potential in the presence of laccase. Dokl. Akad. Nauk SSSR 1978, 240, 615-618.

(4) Tarasevich, M. R.; Yaropolov, A. I.; Bogdanovskaya, V. A.; Varfolomeev, S. D. Electrocatalysis of a cathodic oxygen reduction by laccase. Bioelectrochem. Bioenerg. 1979, 6, 393-403.

(5) Tsujimura, S.; Nakagawa, T.; Kano, K.; Ikeda, T. Kinetic study of direct bioelectrocatalysis of dioxygen reduction with bilirubin oxidase at carbon electrodes. Electrochemistry 2004, 72, 437-439.

(6) Shleev, S.; Christenson, A.; Serezhenkov, V.; Burbaev, D.; Yaropolov, A.; Gorton, L.; Ruzgas, T. Electrochemical redox transformations of $\mathrm{T} 1$ and $\mathrm{T} 2$ copper sites in native Trametes hirsuta laccase at gold electrode. Biochem. J. 2005, 385, 745-754.

(7) Shleev, S.; Tkac, J.; Christenson, A.; Ruzgas, T.; Yaropolov, A. I.; Whittaker, J. W.; Gorton, L. Direct electron transfer between coppercontaining proteins and electrodes. Biosens. Bioelectron. 2005, 20, 2517-2554.

(8) Gelo-Pujic, M.; Kim, H. H.; Butlin, N. G.; Palmore, G. T. Electrochemical studies of a truncated laccase produced in Pichia pastoris. Appl. Environ. Microbiol. 1999, 65, 5515-5521.

(9) Hyung, K. H.; Jun, K. Y.; Hong, H.-G.; Kim, H. S.; Shin, W. Immobilization of laccase onto the gold electrode using bmercaptopropionate. Bull. Korean Chem. Soc. 1997, 18, 564-566.

(10) Yoon, C.-J.; Kim, H.-H. Electrochemical studies of immobilized laccases on the modified-gold electrodes. J. Korean Electrochem. Soc. 2004, 7, 26-31. 
(11) Ramirez, P.; Mano, N.; Andreu, R.; Ruzgas, T.; Heller, A.; Gorton, L.; Shleev, S. Direct electron transfer from graphite and functionalized gold electrodes to T1 and T2/T3 copper centers of bilirubin oxidase. Biochim. Biophys. Acta 2008, 1777, 1364-1369.

(12) Haberska, K.; Vaz-Dominguez, C.; De Lacey, A. L.; Dagys, M.; Reimann, C. T.; Shleev, S. Direct electron transfer reactions between human ceruloplasmin and electrodes. Bioelectrochemistry 2009, 76, 3441.

(13) Guo, L. H.; Hill, H. A. O. Direct electrochemistry of proteins and enzymes. Adv. Inorg. Chem. 1991, 36, 341-375.

(14) Christenson, A.; Shleev, S.; Mano, N.; Heller, A.; Gorton, L. Redox potentials of the blue copper sites of bilirubin oxidases. Biochim. Biophys. Acta 2006, 1757, 1634-1641.

(15) Shleev, S.; Pita, M.; Yaropolov, A. I.; Ruzgas, T.; Gorton, L. Direct heterogeneous electron transfer reactions of Trametes hirsuta laccase at bare and thiol-modified gold electrodes. Electroanalysis 2006, 18, 1901-1908.

(16) Pita, M.; Shleev, S.; Ruzgas, T.; Fernandez, V. M.; Yaropolov, A. I.; Gorton, L. Direct heterogeneous electron transfer reactions of fungal laccases at bare and thiol-modified gold electrodes. Electrochem. Commun. 2006, 8, 747-753.

(17) dos Santos, L.; Climent, V.; Blanford, C. F.; Armstrong, F. A. Mechanistic studies of the blue $\mathrm{Cu}$ enzyme, bilirubin oxidase, as a highly efficient electrocatalyst for the oxygen reduction reaction. Phys. Chem. Chem. Phys. 2010, 12, 13962-13974.

(18) Climent, V.; Zhang, J.; Friis, E. P.; Oestergaard, L. H.; Ulstrup, J. Voltammetry and single-molecule in situ scanning tunneling microscopy of laccases and bilirubin oxidase in electrocatalytic dioxygen reduction on $\mathrm{Au}(111)$ single-crystal electrodes. J. Phys. Chem. C 2012, 116, 1232-1243.

(19) Pita, M.; Gutierrez-Sanchez, C.; Olea, D.; Velez, M.; GarciaDiego, C.; Shleev, S.; Fernandez, V. M.; De Lacey, A. L. High redox potential cathode based on laccase covalently attached to gold electrode. J. Phys. Chem. C 2011, 115, 13420-13428.

(20) Olejnik, P.; Palys, B.; Kowalczyk, A.; Nowicka, A. M. Orientation of laccase on charged surfaces. Mediatorless oxygen reduction on amino- and carboxyl-ended ethylphenyl groups. J. Phys. Chem. C 2012, 116, 25911-25918.

(21) Murata, K.; Kajiya, K.; Nakamura, N.; Ohno, H. Direct electrochemistry of bilirubin oxidase on three-dimensional gold nanoparticle electrodes and its application in a biofuel cell. Energy Environ. Sci. 2009, 2, 1280-1285.

(22) Qiu, H.; Xu, C.; Huang, X.; Ding, Y.; Qu, Y.; Gao, P. Immobilization of laccase on nanoporous gold: comparative studies on the immobilization strategies and the particle size effects. J. Phys. Chem. C 2009, 113, 2521-2525.

(23) Dagys, M.; Haberska, K.; Shleev, S.; Arnebrant, T.; Kulys, J.; Ruzgas, T. Laccase-gold nanoparticle assisted bioelectrocatalytic reduction of oxygen. Electrochem. Commun. 2010, 12, 933-935.

(24) Gutierrez-Sanchez, C.; Pita, M.; Vaz-Dominguez, C.; Shleev, S.; De Lacey, A. L. Gold nanoparticles as electronic bridges for laccasebased biocathodes. J. Am. Chem. Soc. 2012, 134, 17212-17220.

(25) Salaj-Kosla, U.; Poller, S.; Schuhmann, W.; Shleev, S.; Magner, E. Direct electron transfer of Trametes hirsuta laccase adsorbed at unmodified nanoporous gold electrodes. Bioelectrochemistry 2013, 91, $15-20$.

(26) Zhou, H.-X.; Dill, K. A. Stabilization of proteins in confined spaces. Biochemistry 2001, 40, 11289-11293.

(27) Shleev, S.; Reimann, C. T.; Serezhenkov, V.; Burbaev, D.; Yaropolov, A. I.; Gorton, L.; Ruzgas, T. Autoreduction and aggregation of fungal laccase in solution phase: possible correlation with a resting form of laccase. Biochimie 2006, 88, 1275-1285.

(28) Ehresmann, B.; Imbault, P.; Weil, J. H. Spectrophotometric determination of protein concentration in cell extracts containing tRNA and rRNA. Anal. Biochem. 1973, 54, 454-463.

(29) Truesdale, G. A.; Downing, A. L. Solubility of oxygen in water. Nature 1954, 173, 1236.
(30) De Feijter, J. A.; Benjamins, J.; Veer, F. A. Ellipsometry as a tool to study the adsorption behavior of synthetic and biopolymers at the air-water interface. Biopolymers 1978, 17, 1759-1772.

(31) McCrackin, F. L.; Passaglia, E.; Stromberg, R. R.; Steinberg, H. L. Measurement of the thickness and refractive index of very thin films and the optical properties of surfaces by ellipsometry. J. Res. Natl. Bur. Stand., Sect. A 1963, 67, 363-77.

(32) Cuypers, P. A.; Corsel, J. W.; Janssen, M. P.; Kop, J. M. M.; Hermens, W. T.; Hemker, H. C. The adsorption of prothrombin to phosphatidylserine multilayers quantitated by ellipsometry. J. Biol. Chem. 1983, 258, 2426-2431.

(33) Tiberg, F. Physical characterization of non-ionic surfactant layers adsorbed at hydrophilic and hydrophobic solid surfaces by timeresolved ellipsometry. J. Chem. Soc., Faraday Trans. 1996, 92, 531538.

(34) Voeroes, J. The density and refractive index of adsorbing protein layers. Biophys. J. 2004, 87, 553-561.

(35) Horcas, I.; Fernandez, R.; Gomez-Rodriguez, J. M.; Colchero, J.; Gomez-Herrero, J.; Baro, A. M. WSXM: a software for scanning probe microscopy and a tool for nanotechnology. Rev. Sci. Instrum. 2007, 78, 013705/1-013705/8.

(36) Pankratov, D. V.; Zeifman, Y. S.; Morozova, O. V.; Shumakovich, G. P.; Vasil'eva, I. S.; Shleev, S.; Popov, V. O.; Yaropolov, A. I. A comparative study of biocathodes based on multiwall carbon nanotube buckypapers modified with three different multicopper oxidases. Electroanalysis 2013, 25, 1143-1149.

(37) Shleev, S.; Andoralov, V.; Falk, M.; Reimann, C. T.; Ruzgas, T.; Srnec, M.; Ryde, U.; Rulisek, L. On the possibility of uphill intramolecular electron transfer in multicopper oxidases: electrochemical and quantum chemical study of bilirubin oxidase. Electroanalysis 2012, 24, 1524-1540.

(38) Andoralov, V.; Falk, M.; Suyatin Dmitry, B.; Granmo, M.; Sotres, J.; Ludwig, R.; Popov Vladimir, O.; Schouenborg, J.; Blum, Z.; Shleev, S. Biofuel cell based on microscale nanostructured electrodes with inductive coupling to rat brain neurons. Sci. Rep. 2013, 3, 3270.

(39) Caruso, F.; Furlong, D. N.; Kingshott, P. Characterization of ferritin adsorption onto gold. J. Colloid Interface Sci. 1997, 186, 129140 .

(40) Margeat, E.; Le Grimellec, C.; Royer, C. A. Visualization of trp repressor and its complexes with DNA by atomic force microscopy. Biophys. J. 1998, 75, 2712-2720.

(41) Moreno-Herrero, F.; Colchero, J.; Baro, A. M. DNA height in scanning force microscopy. Ultramicroscopy 2003, 96, 167-174.

(42) Maartensson, J.; Arwin, H. Interpretation of spectroscopic ellipsometry data on protein layers on gold including substrate-layer interactions. Langmuir 1995, 11, 963-968.

(43) Tsujimura, S.; Kuriyama, A.; Fujieda, N.; Kano, K.; Ikeda, T. Mediated spectroelectrochemical titration of proteins for redox potential measurements by a separator-less one-compartment bulk electrolysis method. Anal. Biochem. 2005, 337, 325-331.

(44) Christensen, N. J.; Kepp, K. P. Stability mechanisms of a thermophilic laccase probed by molecular dynamics. PLoS One 2013, 8 , e61985.

(45) Ortiz, R.; Matsumura, H.; Tasca, F.; Zahma, K.; Samejima, M.; Igarashi, K.; Ludwig, R.; Gorton, L. Effect of deglycosylation of cellobiose dehydrogenases on the enhancement of direct electron transfer with electrodes. Anal. Chem. 2012, 84, 10315-10323.

(46) Yakovleva, M. E.; Killyeni, A.; Seubert, O.; O Conghaile, P.; MacAodha, D.; Leech, D.; Gonaus, C.; Popescu, I. C.; Peterbauer, C. K.; Kjellstroem, S.; Gorton, L. Further insights into the catalytical properties of deglycosylated pyranose dehydrogenase from Agaricus meleagris recombinantly expressed in Pichia pastoris. Anal. Chem. 2013, $85,9852-9858$.

(47) Lee, S.-K.; DeBeer George, S.; Antholine, W. E.; Hedman, B.; Hodgson, K. O.; Solomon, E. I. Nature of the intermediate formed in the reduction of $\mathrm{O}_{2}$ to $\mathrm{H}_{2} \mathrm{O}$ at the trinuclear copper cluster active site in native laccase. J. Am. Chem. Soc. 2002, 124, 6180-6193. 